\title{
SAFETY AND RISK AS PART OF RAILWAY SYSTEM
}

\author{
Silvia ČIČMANCOVÁ ${ }^{1}$
}

Review article

Abstract:
Some safety system is the problem of our age. The article deals with the safety of the
railway system and risks, risks that may negatively affect the safety. It presents the basic
elements and components safety of the railway system. Briefly describes the method
of focusing on security. The main essences of the article are the risks and the article is
focused on characteristics of their causes of railway system safety, which are identified by
the method - Ishikawa diagram. The last part of the article is devoted to the acceptability
of the risk in the railway system.
Safety, railway system, risk, common safety method, acceptability.

\section{Introduction}

Safety is defined as a property of a system which does not in any way endanger neither persons nor its environment. Another definition is a removal of inacceptable risk. Railway system is a system affected by various stochastic influences. These are i.e. human errors, unforeseen failures, and different combinations of unfavorable situations which may negatively influence the safety of various elements or even of the whole railway system.

Since there is no such thing as zero risk, it is not possible to reach an absolute safety. To recognize potential danger it is necessary to isolate all potential sources of danger. This can be done using a proper method.

Safety of a railway system is dependent on the balance of following three elements: "man machine - environment". Neglecting one of the elements may cause a system imbalance as result of negative externality and thus interrupt the operation execution.

These three concepts and their interrelations are addressed ergonomic system. The goal of optimization of ergonomic system is to ensure well-being of humans and prevent any injuries caused by accidents. The relationship of the three components of the system is shown on figure 1 . Many see a human in railway system only as train driver. However, railway system includes all persons directly connected to the operation of rail vehicle. This includes other railway employees (train dispatchers, transiters and others) and all people influencing the railway system.

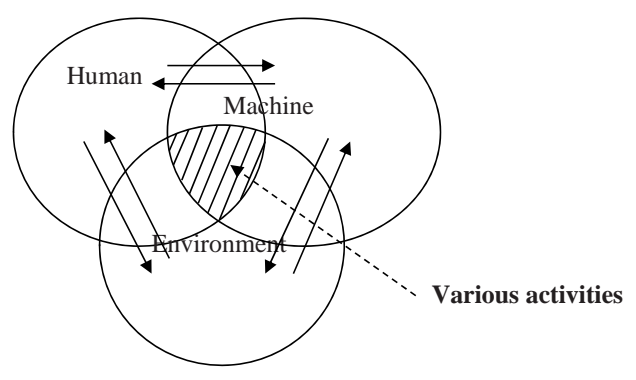

Fig. 1 The relationship of the three components of the system (HITKA, 2008 - redesigned)

The term "Machine" means railway vehicle which may under certain circumstances disrupt the functionality of the railway system. The circumstances may be i.e. bad technical condition, derailing of the vehicle and others.

Environment is another element of railway system, which directly influences safety of the system. Railway vehicle exists in certain environment in which other necessary machines and devices are used, and various activities are performed. The arrows represent the links between elements

\section{Materials and methods}

\section{Legal environment}

Slovak republic has passed several legal bills regarding the railway system safety after its integration into the European Union. The directive 2004/49/ES has introduced a railway safety (directive 2004/49/ec of the european parliament 
and of the council of 29 April 2004 on safety on the Community's railways or Railway Safety Directive), which is a new competence of the European Union.

Railway Safety Directive deals in:

- definitions (railway system, safety management system, serious accident and other),

- safety certificates,

- safety authority,

- accident and incident investigation,

- and others (Railway Safety Directive, 2004).

Interoperability is closely related to the railway safety. Interoperability mirrors the ability of the existing railway system to provide for safe and undisturbed movement of trains reaching the level of performance required by the railway system. It is defined according to the directive regarding the interoperability of railway systems nr. 2008/57/ ES (Directive 2008/57/ec of the european parliament and of the council Of 17 June 2008 on the interoperability of the rail system within the Community).

Directive deals in:

- definitions (interoperability, network, technical specification for interoperability, harmonized standard),

- technical specifications for interoperability,

- interoperability constituents,

- authorization for types of vehicles,

- and others (Directive on interoperability, 2008).

Safety requirements are regarded in the railways act, 2009 NO 513 of 2009. It defines a minimum safety level expressed via acceptable risk level. This defined minimum safety has to be reached by all elements of railway system.

Railway law deals in:

- railway protection zone,

- interoperability railway system,

- authorizing the placing railway vehicles (Railways Act, 2009).

It is necessary to create an integrated railway space which will also concern the railway safety, because there are various problems regarding common solutions.

As a most suitable tool, the European Railway Agency has been found in year 2004. It resides in the French city of Valenciennes.

It represents an important part in the politics of modernization of European railway sector. The agency is concerned by implementation of various agendas such as railway safety, interoperability, common standards for European railways and economic evaluation. These are shown in the figure 2 .

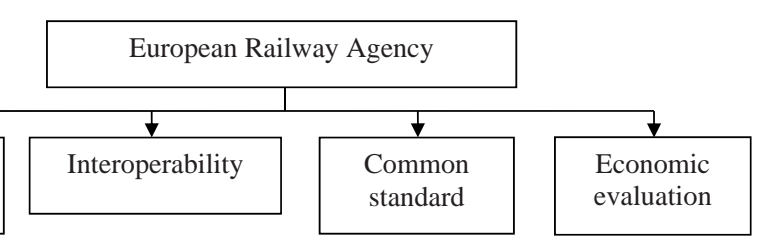

Fig. 2 Agenda of the European Railway Agency (ERA, 2006)

The agenda of common standards regards introduction of common signaling standards in railway transport within the whole EU. The Agency also acts as the system authority for the European Rail Traffic Management System (ERTMS) project, which has been set up to create unique signaling standards throughout Europe. Economic evaluation is an essential feature common to all activities of the Agency.

The main obstacles in railway development are incompatible technical and safety standards within the member countries. The main goal of the European Railway Agency is a step by step harmonization of those incompatible standards. Last, but not least is an implementation of common safety targets and methodic for the whole European railway system.

\section{Components of the railway safetysystem}

Safety of a railway system is characterized by three basic components. These are safety indicators, safety targets and safety method.

\section{Safety indicators}

Safety indicators (Tab. 1) are information regarding the railway system safety which allows comparing the system safety level to the safety targets.

\section{Safety targets}

Based on the above mentioned indicators, the safety targets are set. Safety target represents a minimum safety level expressed by acceptable risks which have to be reached by all elements of the railway system. The target is to maintain the safety of the whole system via minimization of risks (Railway Safety Directive, 2004).

The European railway agency has developed a method serving a purpose of describing ways to assess the safety level, reach the safety targets and observe other requirements regarding the railway safety. 
Tab. 1 Distribution of the Safety indicators (Railway Safety Directive, 2004)

\begin{tabular}{|c|c|c|c|c|}
\hline \multicolumn{5}{|c|}{ Indicators relating to } \\
\hline accidents & $\begin{array}{l}\text { incidents and } \\
\text { near-misses } \\
\text { (number of) }\end{array}$ & $\begin{array}{l}\text { consequences of } \\
\text { accidents (costs in } \\
\text { euro) }\end{array}$ & $\begin{array}{c}\text { technical safety of } \\
\text { infrastructure and its } \\
\text { implementation (percentage of) }\end{array}$ & $\begin{array}{c}\text { the management } \\
\text { of safety }\end{array}$ \\
\hline $\begin{array}{l}\text { - collisions of trains, } \\
\text { - suicides } \\
\text { - fires in rolling } \\
\text { stock } \\
\text { - others }\end{array}$ & $\begin{array}{l}\text { - } \text { broken rails } \\
\text { - } \text { track buckles } \\
\text { - signals passed } \\
\text { at danger } \\
\text { - broken wheels } \\
\text { - others }\end{array}$ & $\begin{array}{l}\text { - deaths and injuries } \\
\text { - delays, disturbances } \\
\text { and re-routing of } \\
\text { traffic } \\
\text { - replacement or } \\
\text { repair of damaged } \\
\text { rolling stock }\end{array}$ & $\begin{array}{l}\text { - tracks with Automatic Train } \\
\text { Protection } \\
\text { - level crossings with automatic } \\
\text { or manual protection }\end{array}$ & $\begin{array}{l}\text { - number of } \\
\text { internal audits } \\
\text { - percentage of } \\
\text { audits required }\end{array}$ \\
\hline
\end{tabular}

Safety indicators represent parameters defining the railway safety level. Safety indicators comprise the system elements.

\section{Safety method}

Common safety method (CSM) introduces a harmonized approach to risk evaluation, which is necessary for the integrated railway space. The integrated railway space has become one of the main priorities of the EU. It requires strict European legal decrees mostly in the area of safety requirements. CSM (figure 3) is used when it is necessary to assess major changes to the railway system in any member state. The CSM is in use since July $1^{\text {st }}, 2012$.

CSM involves following steps:

- the risk assessment process, which includes activities such as system definition, risk analysis and risk evaluation,

- demonstration of the compliance with the specified requirements of the identified security system,

- management of all of the identified risks and hazards (Dvořák, 2010).

Each proposed change presents a certain risk, which could result in substantial negative consequences. Therefore, it is appropriate to use risk assessment of the changes to the CSM method. The first step of CSM has to determine the significance of the changes.

The proposed changes can be e.g. change in the working time of the drivers, change in speed, the introduction of a new vehicle type, the change in the situation when the guide will not be in the train, and many others.

The change is considered to be significant if it meets the criteria where the proposed change has an impact on safety of railway system.

These criteria are:

- failure consequence - credible worst-case scenario in the event of failure of the system under assessment, taking into account the existence of safety barriers outside the system,
- novelty used in implementing the change: this concerns both what is innovative in the railway sector, and what is new just for the organization implementing the change,

- complexity of the change,

- monitoring - the inability to monitor the implemented change throughout the system life-cycle and take appropriate interventions,

- reversibility - the inability to revert to the system before the change,

- additionality - assessment of the significance of the change taking into account all recent safety-related modifications to the system under assessment and which were not judged as significant (Commission regulation, 2009).

The outcome of the common safety method is controlling of the dangers regarding the defined change.

It is necessary to allow enough time for understanding the method, so that the affected ones may get know the new common approach. There is not standard method in Slovak Republic for assessing safety risks in railway system. It is therefore necessary to verify the usability of the common safety method.

\section{Results}

\section{Risk and its acceptability}

The figure 4 shows an Ishikawa diagram where on the main axis shows a problem representing a disturbance in the railway system safety. Branches of the diagram depict different influences causing the problem. Disturbance of the railway system may cause risk for: 
- employees,

- passengers,

- unauthorized persons in the area of the railroad tracks,

- members of the road traffic,

- society.
Each risk has various causes which are shown on the figure as decomposition of diagram branches. Employees and passengers are regarded as a primary group affected by the risk.

Railways employees are people taking part in the transportation process. Employees working in

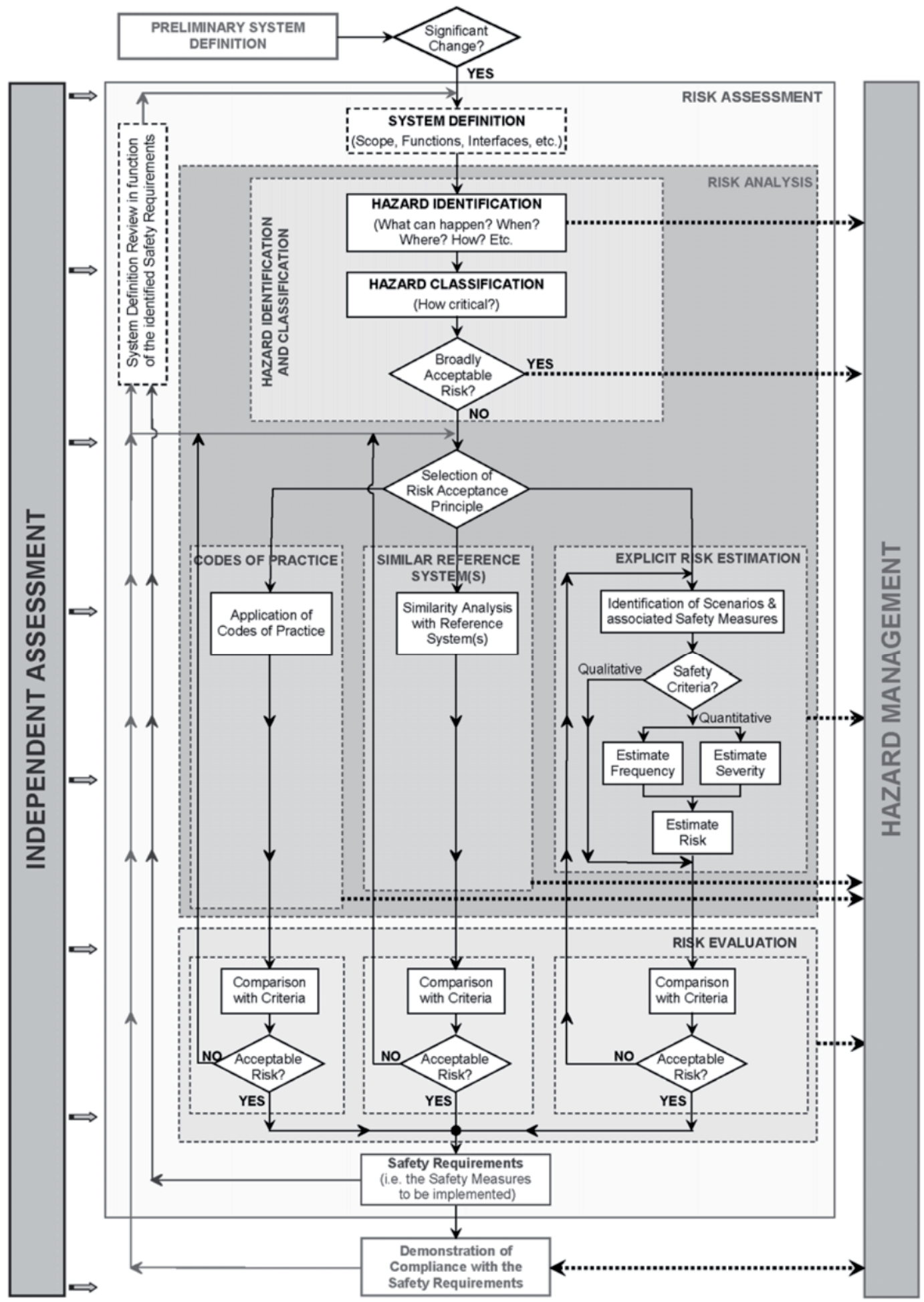

Fig. 3 Risk management process and independent assessment (Breyne and Jovicic, 2010) 
i.e. the railway stations, maintenance, transiters, train drivers all fall in this category. The occurrence of risk for the employees may be caused by different events such as train crash, human error (at railroad maintenance), terrorist attack, assault by passenger and others.

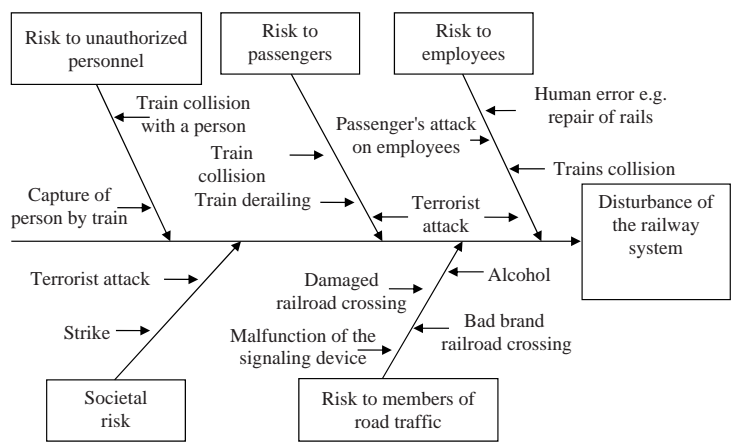

Fig. 4 Reasons of disturbance of safety of railway system

Passengers are not to be understood only as persons in the train, but also ones waiting in the railway station. Risk for the passengers may be caused by i.e. trains collision, train derailing and/ or terrorist attack. One of the main properties of the terrorist attack is to assault large number of people. Train station or railway vehicle are places with high density of people (passengers, employees and others). Other risk causes may include i.e. explosion of the reservoir with dangerous material, various injuries caused by i.e. fall from the railway vehicle.

In the area of the railroad tracks there may be unauthorized personnel. Such persons are undertaking various risks, i.e. of taking part in a train accident, direct exposure to dangerous material and others.

Collisions of trains with the members of road traffic at the railroad crossings are considered as a big part of the railroad accidents. Causes of such accidents include malfunction of the signaling device, damaged railroad crossing, or driving under influence of alcohol or other substances.

Society or collective risk may be caused by possible terrorist attack or strike.

The diagram offers a possibility of in-depth understanding of causes for risk occurrence and thus possibility of implementation of suitable remedies.

The important question regards the risk acceptability - what risk level is still acceptable. Organization and individuals have to often decide what levels of risks are considered as acceptable. However, a level of risk acceptable for one entity may not be acceptable for other entity. This shows that the risk acceptance is entirely subjective. For example, it is required by law that in Great Britain is risk to be maintained as low as reasonably practicable (ALARP) - Fig. 5.

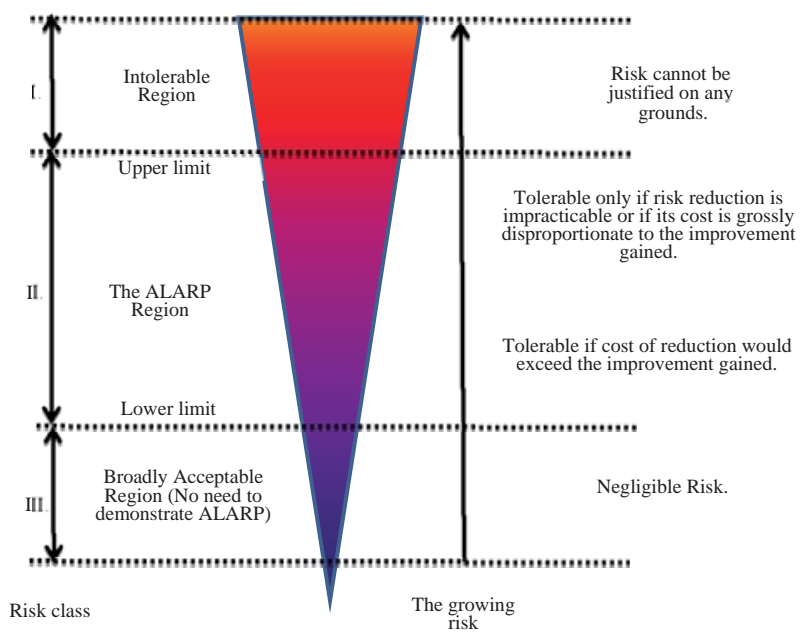

Fig. 5 ALARP model (Redmill, 2010)

This has been declared by the British agency for health and safety. This model regards also economical point of view necessary to lower the risk. With the ALARP model it is necessary to assess residual risk and include a proof that it is not reasonably possible lower the risk any further. As shown on the figure 5, ALARP determinates three risk regions. In case the risk level reaches an unacceptable region, it is necessary to lower the risk level at least to the next acceptable one. If the risk level is in the lowest region, it is considered to be negligible and acceptable without any further restrictions. However, it is necessary to check regularly whether the risk remains within the acceptable region (Redmill, 2010).

Limit between the broadly acceptable region and ALARP is considered as safe level. However, this does not necessarily imply zero risk level. Similarly, the boundary between ALARP region and intolerable region is considered as dangerous level, although it does not mean indivertible catastrophe or even maximum risk level.

The width of the triangle in the ALARP model represents the economical means needed to lower the risk. In other words: the higher the risk, the higher the required expenses for its suppression.

This does not necessarily mean that substantial risk suppression means substantial expenses. In many cases it is possible to achieve substantial risk suppression with negligible expenses.

Important part of ALARP model is defined limit. The upper limit of tolerability is usually defined and is derived from the statistics of accidents. Lower limit is sometimes defined, sometimes not. 
Examples of particular value define the upper and lower limits (Fig. 6).

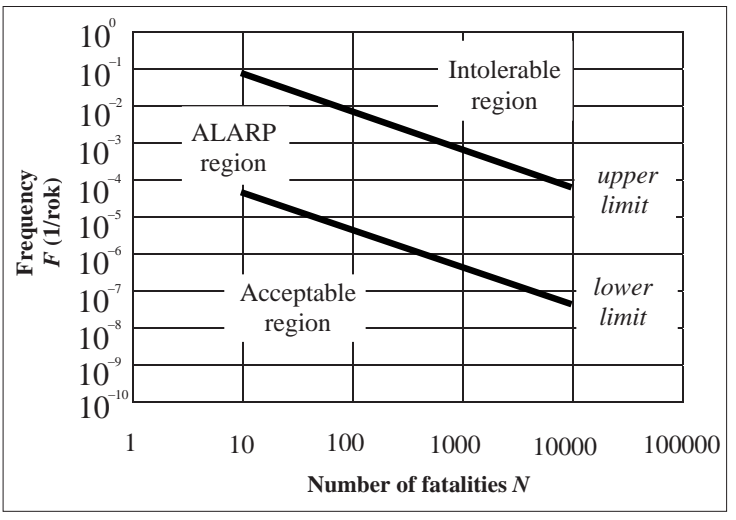

Fig. 6 The limits of acceptability (PŘIBYL, 2008)

\section{Conclusion}

In each system there is possibility for its disturbance. It is necessary to address the problem of raising the safety of the railway system with priority on preventing serious accidents using the newest scientific and technological advances. The question of safety is very complicated, because there is no hundred percent safety, and I consider it very important to continuously monitor the required safety level of the system. The article is for information only.

The CSM is to be verified, which is my goal of doctoral study. Since I am only at the beginning of the second year of study, I am receiving information about the safety of the railway system and the CSM. My main focus of the study is the risk assessment in the transport.

\section{References}

BREYNE, Thierry, JOVICIC, Dragan (2009). Spoločná bezpečnostná metóda (SBM) hodnotenia a posudzovania rizik [online]. Európska železničná agentúra, [cit. 2013-08-28]. Available at: http://www.era.europa.eu/ Document-Register/Documents/ERA-2009-0048-00-00-SK.pdf. (in Slovak)

DVOŘAK, Zdeněk (2010). Risk management in rail transport, Pardubice 2010, 287 p. ISBN 978-80-86530-71-0. (in Slovak)

EURÓPSKA ŽELEZNIČNÁ AGENTÚRA (ERA) [online]. Visegrad EU portals. [cit. 2013-02-15] Available at: http://www.europskaunia.sk/agentura_spolocenstva_era. (in Slovak)

HITKA, Miloš (2008). Ergonómia [online], [cit. 2013-08-30]. Available at: http://www.google.sk/url?sa=t\&rct= $\mathrm{j} \& \mathrm{q}=\& \mathrm{esrc}=\mathrm{s} \&$ source $=$ web\& $\mathrm{cd}=1 \& \mathrm{ved}=0 \mathrm{CC} 8 \mathrm{QFjAA} \& u r \mathrm{l}=\mathrm{http} \% 3 \mathrm{~A} \% 2 \mathrm{~F} \% 2 \mathrm{Fwww} \cdot \mathrm{miloshitka} . \mathrm{szm} . \operatorname{com} \% 2$ Fergonomia1.ppt\&ei=Q1HFUtGBGImItQa0nIGIBg\&usg=AFQjCNHvOa02zBbWHxaNeusrZ56V0J5U7 g\&bvm=bv.58187178,d.Yms

NARIADENIE KOMISIE (ES) č. 352/2009 z 24. apríla 2009 o prijatí spoločnej bezpečnostnej metódy hodnotenia a posudzovania rizík, ako sa uvádza v článku 6 ods. 3 písm. a) smernice Európskeho parlamentu a Rady 2004/49/ES. (in Slovak)

PǨIBYL, Pavel, JANOTA, Aleš, SPALEK, Juraj (2008). Risk analysis and management in transport. Praha: BEN, 2008, 560 p. ISBN 978-80-7300-214-5. (in Czech)

RAILWAYS ACT (2009). NO 513 of 2009. (in Slovak)

REDMILL, Felix (2010). ALARP Explored [online]. Newcastle: technical report series [cit. 2013-09-05] Available at: http://europeanspallationsource.se/sites/default/files/alarp_explored.pdf

SMERNICA 2004/49/ES EURÓPSKEHO PARLAMENTU A RADY z 29. apríla 2004, o bezpečnosti železníc spoločenstva a o zmene a doplnení smernice Rady 95/18/ES o udel'ovaní licencií železničným podnikom a smernici 2001/14/ES o pridel'ovaní kapacity železničnej infraštruktúry, vyberaní poplatkov za používanie železnične infraštruktúry a bezpečnostnej certifikácii. (in Slovak)

SMERNICA EURÓPSKEHO PARLAMENTU A RADY 2008/57/ES zo 17. júna 2008 o interoperabilite systému železníc v Spoločenstve. (in Slovak) 